\title{
Fe-Based Powders Prepared by Ball-Milling with Considerable Degradation Efficiency to Methyl Orange Compared with Fe-Based Metallic Glasses
}

\author{
Sheng-Hui Xie ${ }^{1} \cdot$ Guang-Qiang Peng $^{1} \cdot$ Xian-Meng Tu$^{1} \cdot$ Hai-Xia Qian ${ }^{1} \cdot$ Xie-Rong Zeng $^{1}$ \\ Received: 4 March 2018/Revised: 1 April 2018/Published online: 16 May 2018 \\ (C) The Chinese Society for Metals and Springer-Verlag GmbH Germany, part of Springer Nature 2018
}

\begin{abstract}
In this study, the degradation efficiencies of zero-valent iron (ZVI) powders with different structures and components were evaluated for methyl orange (MO). The results show that the structure is an essential factor that affects degradation, and added non-metallic elements help optimize the structure. The amorphous and balled-milled crystalline $\mathrm{Fe}_{70} \mathrm{Si}_{10} \mathrm{~B}_{20}$ has comparative degradation efficiencies to $\mathrm{MO}$ with $t_{1 / 2}$ values of 6.9 and $7.0 \mathrm{~min}$, respectively. Increasing the boron content can create a favorable structure and promote degradation. The ball-milled crystalline $\mathrm{Fe}_{70} \mathrm{~B}_{30}$ and $\mathrm{Fe}_{43.64} \mathrm{~B}_{56.36}$ powders have relatively short $t_{1 / 2}$ values of 5.2 and $3.3 \mathrm{~min}$, respectively. The excellent properties are mainly attributed to their heterogeneous structure with boron-doped active sites in ZVI. Composition segregation in the nanoscale range in an amorphous $\mathrm{FeSiB}$ alloy and small boron particles in the microscale range embedded in large iron particles prepared by ballmilling, both constitute effective galvanic cells that promote iron electron loss and therefore decompose organic chemicals. These findings may provide a new, highly efficient, low-cost commercial method for azo dye wastewater treatment using ZVI.
\end{abstract}

Keywords Fe-based powder $\cdot$ Fe-based metallic glass $\cdot$ Degradation $\cdot$ Methyl orange $\cdot$ Galvanic cell

\section{Introduction}

Azo dyes are mainly synthetic organic dyes containing azo groups, " $-\mathrm{N}=\mathrm{N}-"$, and they are widely used in the textile industry, contributing to approximately $60-70 \%$ of all commercial dyes [1-3]. Azo dyes can lead to acute or chronic biological effects and affect the food chain through azo dye-containing wastewater [4]. However, current methods to remove azo dyes from wastewater have many disadvantages. Physical adsorption methods just collect azo dye molecules together from sewage without breaking the azo dye bonds. So the harmful substances, transferred from one place to another, must undergo secondary treatment

Available online at http://link.springer.com/journal/40195

Sheng-Hui Xie

shenghuixie@163.com

1 Shenzhen Key Laboratory of Special Functional Materials and Shenzhen Engineering Laboratory for Advance Technology of Ceramics, College of Materials Science and Engineering, Shenzhen University, Shenzhen 518060, China
$[5,6]$. Bioremediation requires a great amount of time, and it has low efficiency and high cost [7]. Fenton/Fenton-like oxidation requires hydrogen peroxide, and it has ferric hydroxide sludge as a by-product, which limits reusability during actual industrial-scale applications [8]. Photocatalysis requires expensive UV light sources, and it has a low light utilization efficiency $[9,10]$.

The removal of pollutants from water by ZVI is a new treatment technology since it has low cost and does not need extra energy. ZVI was used to remove Orange II with the help of weak magnetic field. Moreover, the efficiency of decolorization together with TOC (Total Organic Carbon) were enhanced dramatically [11]. A ZVI/granularactivated carbon system was used to remove azo dye Acid Orange 7 in the presence of ultrasound, and a significant synergetic effect was observed between ultrasound and ZVI/granular-activated carbon [12]. Nanoscale zero-valent iron (NZVI) particles were used to degrade methyl orange, and a low activation energy of $35.9 \mathrm{~kJ} / \mathrm{mol}$ and high decolorization efficiency were determined [13]. However, susceptibility to oxidation limits ZVI's further degradation reaction and industrial applications. Recently, Fe-based 
metallic glasses with excellent resistance to oxidation have been developed for the degradation of azo dyes. Zhang et al. [14] found that the degradation efficiency of an $\mathrm{Fe}-$ Mo-Si-B amorphous alloy to Direct Blue 2B was up to 4 times that of crystallized ribbons. Lin et al. [15] utilized the $\mathrm{Fe}_{78} \mathrm{Si}_{9} \mathrm{~B}_{13}$ metallic glass to remove organic matter and found that it had 25 times faster degradation than crystalline ZVI. Wang et al. [16] made comparisons of the degradation of Direct Blue 6 using ball-milled $\mathrm{Fe}_{73} \mathrm{~B}_{17}$ $\mathrm{Nb}_{3} \mathrm{Si}_{7}$ amorphous powders and commercial ZVI and found that the ball-milled powders had approximately 200 times higher degradation efficiency. Das et al. [17] reported a complete degradation of direct blue dye using $\mathrm{Fe}_{48} \mathrm{Cr}_{15}$ $\mathrm{Mo}_{14} \mathrm{Y}_{2} \mathrm{C}_{15} \mathrm{~B}_{6}$ metallic glass was obtained in less than 20 min. Compared with commercially available crystalline ZVI, Fe-based metallic glasses usually demonstrate superior catalytic properties due to their excellent corrosion resistance and their unique metastable thermodynamic nature $[16,18]$. Generally, Fe-based metallic glasses used for the degradation of azo dyes contain some metalloid elements, such as silicon and boron, which allow the alloys to be tuned to obtain the required glass structure [19]. We always pay much attention to the role of structure and active element during degradation. However, we ignore the influence of non-metallic elements in Fe-based metallic glasses.

In this study, not only the optimal structure favoring catalytic reaction but also the role of non-ferric elements is evaluated. Fe-based powders with low-priced preparation procedures and high degradation efficiency to MO are proposed in this paper.

\section{Materials and Methods}

\subsection{Materials}

Pure iron, silicon, boron, Fe-B alloy, niobium and molybdenum were supplied by China New Metal Materials Technology Company ( $\geq 99.99 \%$ ), and analytical grade methyl orange $\left(\mathrm{C}_{14} \mathrm{H}_{14} \mathrm{~N}_{3} \mathrm{NaO}_{3} \mathrm{~S}\right)$ was purchased from Shandong Xiya Chemical Industry, China.

\subsection{Preparation of Fe-Based Powders}

The master alloy ingots with nominal compositions of $\mathrm{Fe}_{70} \mathrm{Si}_{10} \mathrm{~B}_{20}$ (at.\%), $\mathrm{Fe}_{73} \mathrm{~B}_{17} \mathrm{Nb}_{3} \mathrm{Si}_{7}$ (at.\%) and $\left(\mathrm{Fe}_{0.99-}\right.$ $\left.\mathrm{Mo}_{0.01}\right)_{78} \mathrm{Si}_{9} \mathrm{~B}_{13}$ (at.\%) were prepared by arc melting mixtures of pure iron, silicon and $\mathrm{Fe}-\mathrm{B}$ alloy in a Ti-gettered high-purity argon atmosphere (VF-AMP30). Then, metallic glass ribbons were prepared via melt-spinning at $36 \mathrm{~m} / \mathrm{s}$ (VF-RQT50) from the ingots. The metallic glass powders (denoted G-ZVI) were produced from the metallic glass ribbons by ball-milling (QM-3SP2) the amorphous ribbons under an $\mathrm{Ar}$ atmosphere for $3000 \mathrm{~min}$ at $300 \mathrm{rpm}$. In order to avoid a contamination from the jars, stainless steel jars and balls with a major ingredient of $\mathrm{Fe}$ were selected. The ball miller rotated and paused at 24-min intervals to avoid possible temperature increase. $\mathrm{Fe}_{70} \mathrm{Si}_{10}$ $\mathrm{B}_{20}, \mathrm{Fe}_{70} \mathrm{Si}_{30}, \mathrm{Fe}_{70} \mathrm{~B}_{30}, \mathrm{Fe}_{90} \mathrm{~B}_{10}$ and $\mathrm{Fe}_{43.64} \mathrm{~B}_{56.36}$ (at.\%) crystalline ZVI alloy powders (denoted C-ZVI) were prepared by ball-milling the pure elements. The ball-milling time was approximately $1800 \mathrm{~min}$ at $300 \mathrm{rpm}$ to ensure a similar particle size distribution and surface topography to the amorphous $\mathrm{Fe}_{70} \mathrm{Si}_{10} \mathrm{~B}_{20}$ powders.

\subsection{Characterizations}

The structures of the G-ZVIs and C-ZVIs were characterized by X-ray diffraction (XRD, D8 Advance) with $\mathrm{Cu}-K_{\alpha}$ radiation at a scan rate of $4 \% \mathrm{~min}$. The surface morphologies and elemental distributions of these samples before and after the degradation were investigated by scanning electron microscopy (SEM, SU-70) and energy-dispersive spectroscopy (EDS). The particle size and distributions were examined using a laser particle size analyzer (BT9300ST). X-ray photoelectron spectroscopy (XPS, Microlab-350) was performed to determine the atomic layer valence change. Degradation experiments were conducted in a $40 \mathrm{~mL}$ MO aqueous solution with an initial concentration of $20 \mathrm{mg} / \mathrm{L}$ by using $0.16 \mathrm{~g}$ reactant. A UVVis spectrophotometer (UV-2450) was used to measure the residual MO concentration to calculate the catalytic capability.

\section{Results and Discussion}

As shown in Fig. 1a, the broad maximum peak with no detectable, crystalline Bragg peaks indicated the amorphous nature of the prepared $\mathrm{Fe}_{70} \mathrm{Si}_{10} \mathrm{~B}_{20}, \mathrm{Fe}_{73} \mathrm{~B}_{17} \mathrm{Nb}_{3} \mathrm{Si}_{7}$ and $\left(\mathrm{Fe}_{0.99} \mathrm{Mo}_{0.01}\right)_{78} \mathrm{Si}_{9} \mathrm{~B}_{13}$ metallic glass powders. In addition, the phase structures of the prepared crystalline powders are shown in Fig. 1b. The silicon and iron diffraction peaks were observed for the $\mathrm{Fe}-\mathrm{Si}$ crystalline powders. For the ball-milled $\mathrm{Fe}_{70} \mathrm{Si}_{10} \mathrm{~B}_{20}$ and $\mathrm{Fe}-\mathrm{B} \mathrm{C}-\mathrm{ZVI}$ powders, only two diffraction peaks were observed at $2 \theta$ of $44.66^{\circ}$ and $65.01^{\circ}$, which were in good agreement with the (110) and (200) planes of $\mathrm{Fe}^{0}$, respectively. No shift was observed for those two diffraction peaks, and no new phases were identified. The solid solution degrees of boron and silicon in iron were 0.0004 and $10 \%$, respectively. Therefore, we assumed that such a large amount of boron or silicon could not enter the iron lattice to form an interstitial solid solution with a short ball-milling time of $1800 \mathrm{~min}$. To determine where the disappeared diffraction 

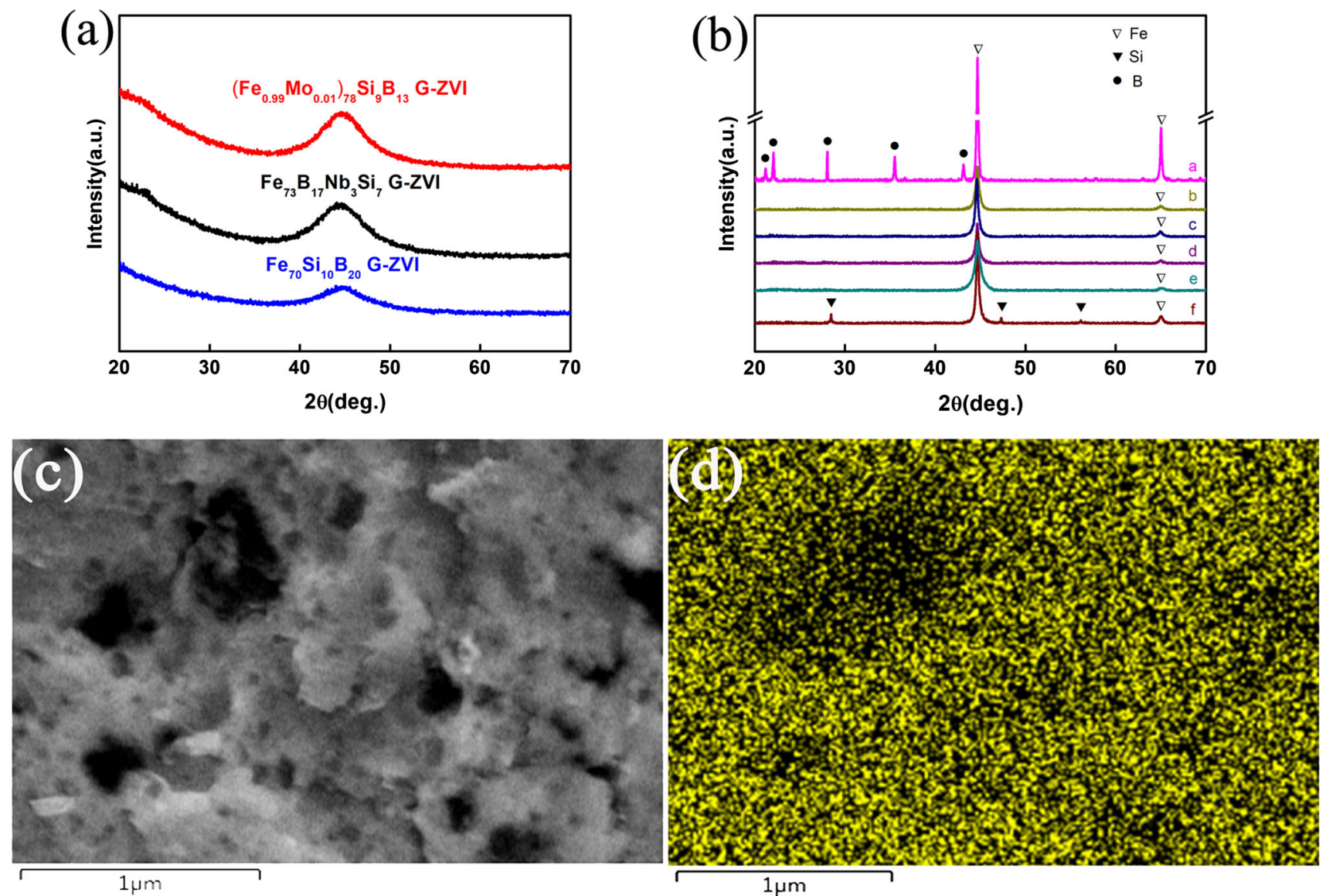

Fig. 1 a XRD patterns of the as-prepared metallic glass powders. $\mathbf{b}$ XRD patterns of the as-prepared crystalline powders $\left(a \mathrm{Fe}_{43.64} \mathrm{~B}_{56.36}\right.$ before ball-milling, $b \mathrm{Fe}_{90} \mathrm{~B}_{10}$ after ball-milling, $c \mathrm{Fe}_{70} \mathrm{~B}_{30}$ after ball-milling, $d \mathrm{Fe}_{43.64} \mathrm{~B}_{56.36}$ after ball-milling, $e \mathrm{Fe}_{70} \mathrm{Si}_{10} \mathrm{~B}_{20}$ after ball-milling, $f \mathrm{Fe}_{70} \mathrm{Si}_{30}$ after ball-milling), c SEM surface morphology of the Fe-B C-ZVI powders after ball-milling. d EDS iron surface analysis at the same area of (c)

peaks were, $\mathrm{Fe}-\mathrm{B}$ mixtures without the ball-milling procedure were examined by XRD under the same experimental conditions with different boron contents. (The results are not shown.) Very low boron diffraction peaks were observed despite the high boron content. Due to the large mass absorption coefficient of iron in the $\mathrm{Cu}-K_{\alpha}$ line, iron can mask the diffraction lines from the boron or silicon particles, which are uniformly embedded into the iron particles after ball-milling [20, 21]. Thus, for the ballmilled $\mathrm{Fe}_{70} \mathrm{Si}_{10} \mathrm{~B}_{20}$ and $\mathrm{Fe}-\mathrm{B}$ powders, no characteristic silicon or boron diffraction peaks were identified, although silicon and boron do exist. We found additional evidence in the EDS surface analysis of the ball-milled crystalline $\mathrm{Fe}_{70} \mathrm{~B}_{30}$ powders. (See Fig. 1c, d.) The bright spots represent the $L_{\alpha}$ lines of iron, and the black particles were inferred to the boron particles, which have sizes similar to those of the initial boron particles. Because boron is harder than pure iron, the boron particles are embedded into the iron particles during the ball-milling.

Figure 2 shows the particle size distribution and average particle size for the as-prepared powders, while the SEM images indicate the surface morphologies. As seen, little difference in the particle size distribution was observed for all the as-prepared powders, and the average particle sizes for $\mathrm{Fe}_{90} \mathrm{~B}_{10} \mathrm{C}-\mathrm{ZVI}, \mathrm{Fe}_{70} \mathrm{~B}_{30} \mathrm{C}-\mathrm{ZVI}, \mathrm{Fe}_{43.64} \mathrm{~B}_{56.36} \mathrm{C}-\mathrm{ZVI}$, $\mathrm{Fe}_{70} \mathrm{Si}_{30}$ C-ZVI, $\mathrm{Fe}_{70} \mathrm{Si}_{10} \mathrm{~B}_{20}$ G-ZVI and $\mathrm{Fe}_{70} \mathrm{Si}_{10} \mathrm{~B}_{20}$ C-ZVI are $14.42,15.42,10.93,10.95,12.23$ and $15.45 \mu \mathrm{m}$, respectively. The similar corrugations can be found on all the ball-milled particles through the SEM images, which are typical surface morphologies after ball-milling. Similar surface morphologies, similar size distribution and similar surface area can be inferred due to the similar ball-milling procedures. Therefore, the particle size and surface influence on the degradation process are neglected in the following discussion.

Figure 3a shows the UV absorption spectra for the MO solutions before and after degradation, and the inset shows the appearance of the MO solutions. Only the results for the $\mathrm{Fe}_{43.64} \mathrm{~B}_{56.36}$ powders are shown in Fig. 3a because similar results were observed for all other reactants. Figure 3a shows two characteristic absorption peaks at 464 and $271 \mathrm{~nm}$ due to the "-N=N-" azo bonding and the benzene ring, respectively. No obvious peak shift in the characteristic absorption peak at $464 \mathrm{~nm}$ was detected, but the 

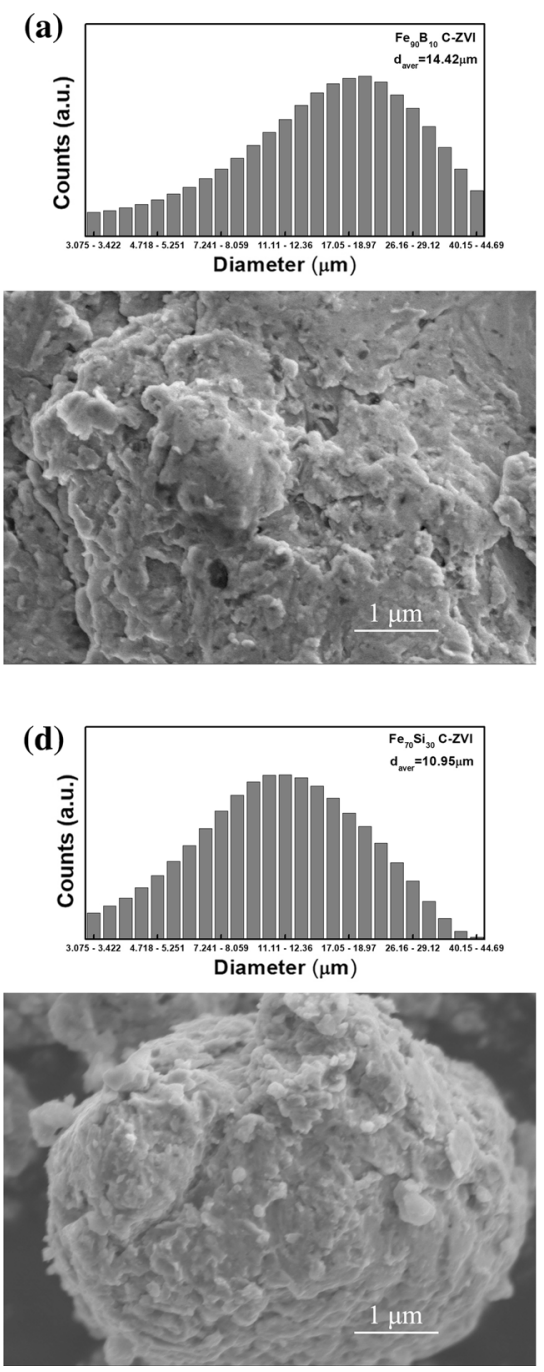

(b)
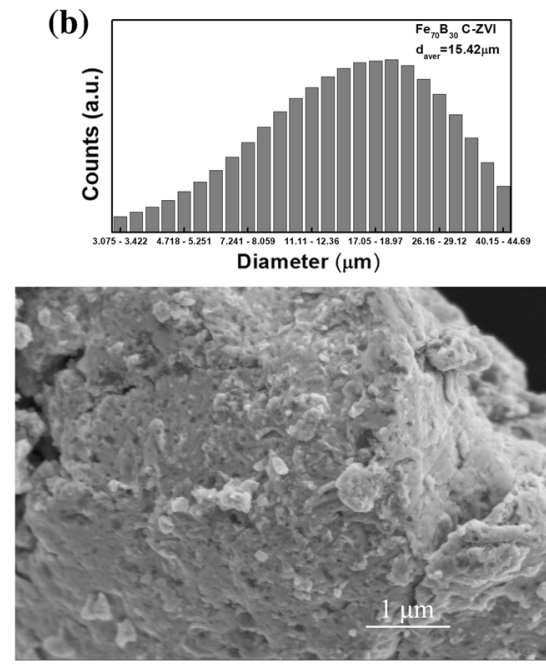

(e)
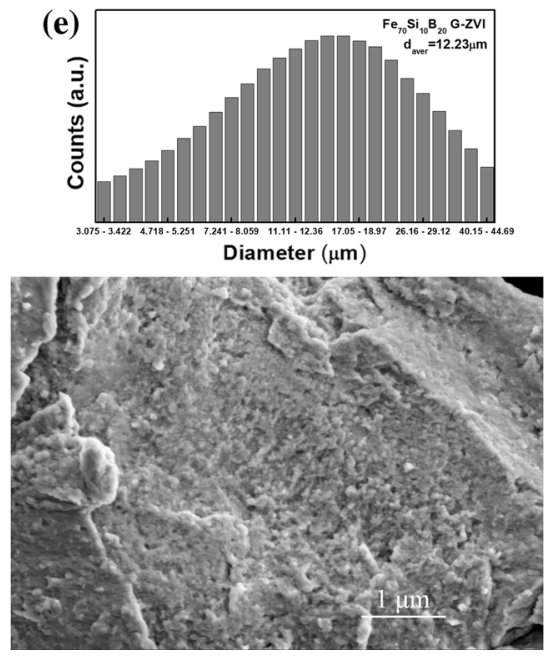
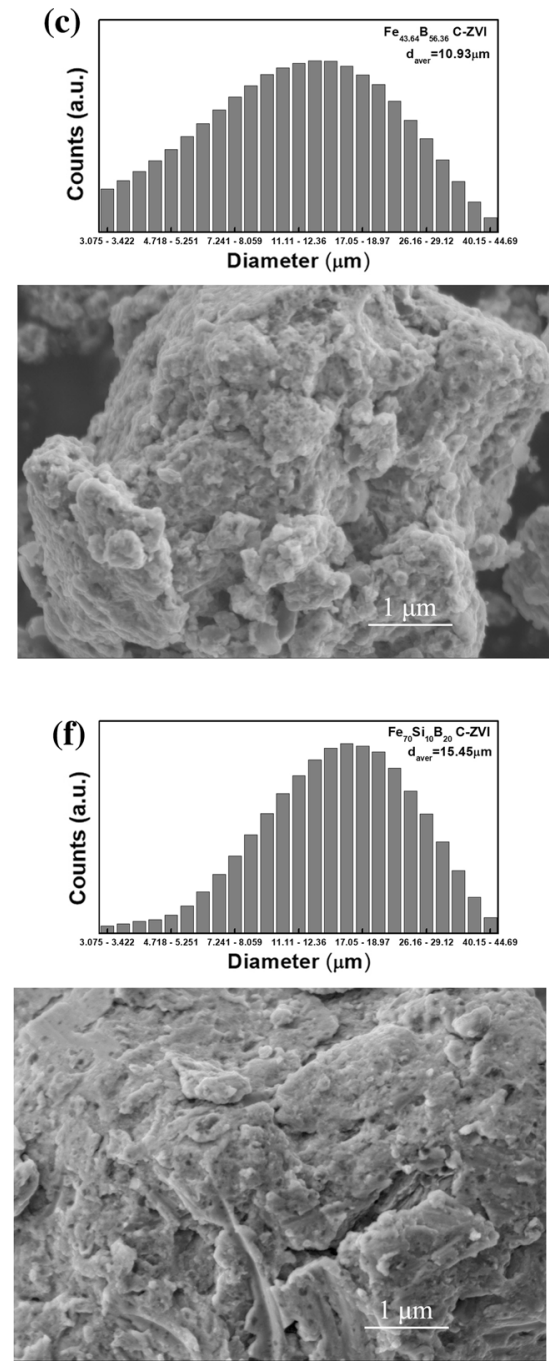

Fig. 2 The size distribution and surface morphologies of the powders after ball-milling; a $\mathrm{Fe}_{90} \mathrm{~B}_{10} \mathrm{C}-\mathrm{ZVI}, \mathbf{b} \mathrm{Fe}_{70} \mathrm{~B}_{30} \mathrm{C}-\mathrm{ZVI}$, c Fe $\mathrm{Fe}_{43.64} \mathrm{~B}_{56.36}$ C-ZVI, d $\mathrm{Fe}_{70} \mathrm{Si}_{30} \mathrm{C}-\mathrm{ZVI}$, e $\mathrm{Fe}_{70} \mathrm{Si}_{10} \mathrm{~B}_{20}$ G-ZVI, f $\mathrm{Fe}_{70} \mathrm{Si}_{10} \mathrm{~B}_{20} \mathrm{C}-\mathrm{ZVI}$

absorption peak of the benzene ring shifted to $246 \mathrm{~nm}$ after the degradation treatment. The intensity of the characteristic absorption peak at $464 \mathrm{~nm}$ eventually decreased as the degradation proceeded, and the peak finally disappeared, which indicated a complete decomposition of MO. Because the absorption intensity at $464 \mathrm{~nm}$ is linearly related to the MO concentration, the decolorization ratio, $D$, was calculated using the following equation [13]:

$D=\frac{C_{0}-C_{t}}{C_{0}} \times 100 \%$,

where $C_{0}$ is the initial concentration and $C_{t}$ is the concentration of MO at reaction time $t$. The dependence of the decolorization ratio calculated from Eq. (1) on time for the different ZVI powders is plotted in Fig. 3b. Clearly, the different ZVI reactants have different degradation efficiencies. The $\mathrm{Fe}_{43.64} \mathrm{~B}_{56.36} \mathrm{C}-\mathrm{ZVI}$ powder had the highest efficiency, and it degraded $99 \%$ of the MO in 50 min. (See
Fig. 3b.) The $\mathrm{Fe}_{70} \mathrm{Si}_{30} \mathrm{C}-\mathrm{ZVI}$ powder had the lowest efficiency and required $120 \mathrm{~min}$ to achieve a $99 \%$ decolorization ratio. The $\mathrm{Fe}_{90} \mathrm{~B}_{10}$ and $\mathrm{Fe}_{70} \mathrm{~B}_{30} \mathrm{C}$-ZVI powders degraded $99 \%$ of the MO in 120 and 60 min, respectively. The results show that boron contributes more to the degradation than silicon, and a higher boron content contributes to a higher degradation efficiency. Interestingly, the same composition $\mathrm{Fe}_{70} \mathrm{Si}_{10} \mathrm{~B}_{20}$ G-ZVI and $\mathrm{Fe}_{70} \mathrm{Si}_{10} \mathrm{~B}_{20}$ $\mathrm{C}-Z \mathrm{VI}$ powders had the same degradation efficiencies (90 min to fully degrade MO) despite their absolutely different structures. To obtain insight on the degradation mechanisms of the different reactants, detailed kinetic investigations were performed at the same temperature. For the degradation process, the MO residual concentration can be expressed by the empirical equation proposed by Shu et al. as follows $[13,22]$ : 

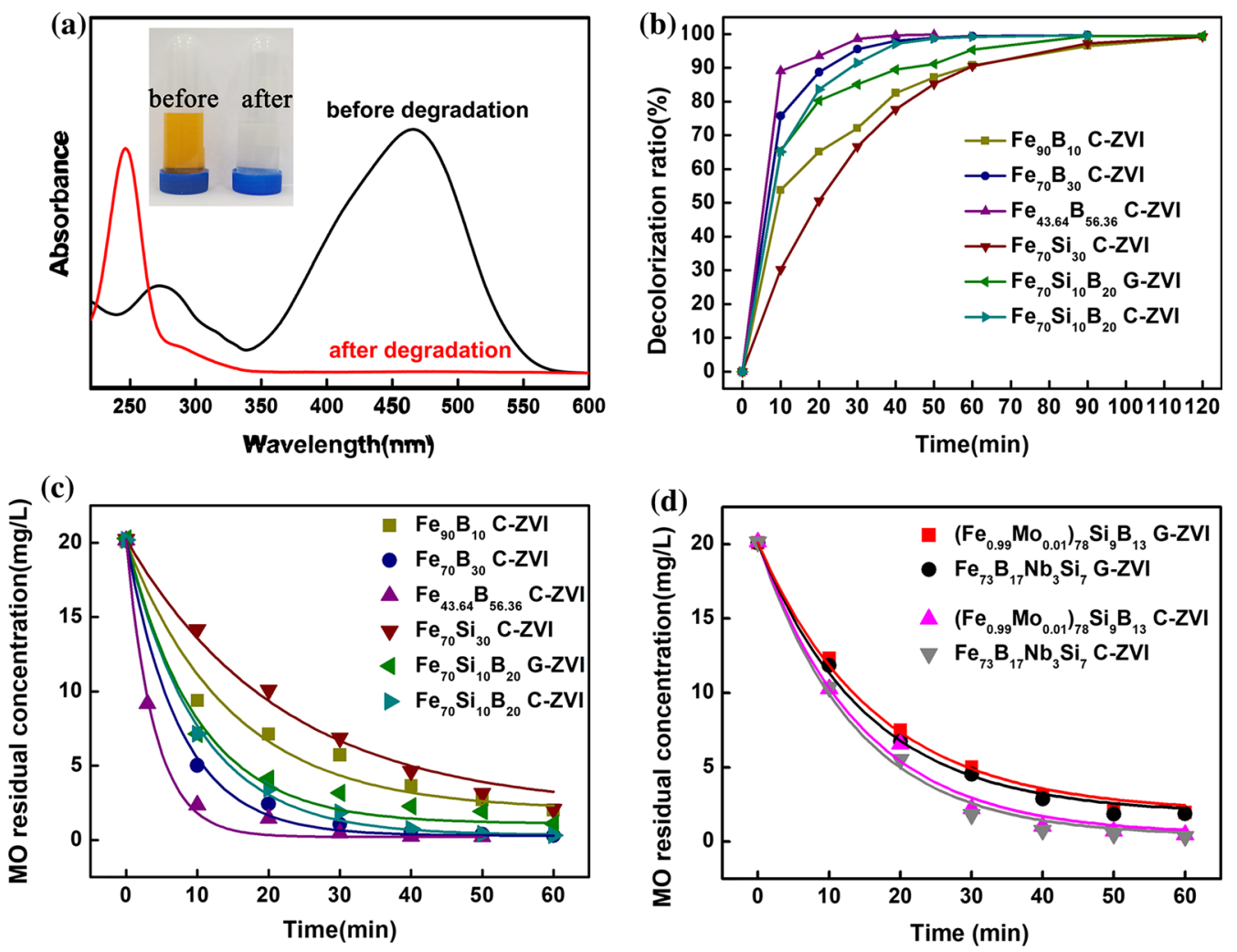

Fig. 3 a Comparison of the UV absorption spectra for the as-prepared and completely degraded MO solutions with $\mathrm{Fe}_{43.64} \mathrm{~B}_{56.36} \mathrm{C}-\mathrm{ZVI}$; inset with the appearance and color change before and after the degradation. b The dependence of the decolorization ratio of different ZVI powders. c The fitting chart of the MO residual concentration for different ZVI powders. $\mathbf{d}$ The fitting chart of the MO residual concentration for $\mathrm{Fe}_{73} \mathrm{~B}_{17} \mathrm{Nb}_{3} \mathrm{Si}_{7}$ and $\left(\mathrm{Fe}_{0.99} \mathrm{Mo}_{0.01}\right)_{78} \mathrm{Si}_{9} \mathrm{~B}_{13}$ G-ZVI and C-ZVIs

$C_{t}^{*}=C_{\text {ultimate }}+\left(C_{0}-C_{\text {ultimate }}\right) \times \exp (-k t)$,

where $C_{t}^{*}$ is the MO residual concentration at reaction time $t, C_{\text {ultimate }}$ is the MO ultimate residual concentration, and $k$ is the observed first-order reaction rate constant. The half-life period $\left(t_{1 / 2}\right.$, the time when the initial concentration of MO has decreased by 50\%) was measured to estimate the degradation capability:

$t_{1 / 2}=\ln (0.5) /(-k)$.

The plots of the MO residual concentration versus time " $t$ " are depicted in Fig. 3c. The results of the nonlinear regression of the experimental data and the half-lives are shown in Table 1. The correlation coefficients $\left(r^{2}\right)$ indicate that the decolorization process was well fitted by first-order exponential decay kinetics. The $\mathrm{Fe}_{43.64} \mathrm{~B}_{56.36} \mathrm{C}$-ZVI powder has the best $k$ and $t_{1 / 2}$ values of $0.213 \mathrm{~min}^{-1}$ and 3.3 min, respectively. The $\mathrm{Fe}_{70} \mathrm{Si}_{30} \mathrm{C}-\mathrm{ZVI}$ powder has the worst $k$ and $t_{1 / 2}$ values of $0.046 \mathrm{~min}^{-1}$ and $15.1 \mathrm{~min}$, respectively. The $\mathrm{Fe}_{70} \mathrm{Si}_{10} \mathrm{~B}_{20}$ G-ZVI and C-ZVI powders have similar $k$ and $t_{1 / 2}$ values $\left(0.100 \mathrm{~min}^{-1}\right.$ and $6.9 \mathrm{~min}$ vs. $0.099 \mathrm{~min}^{-1}$ and $7.0 \mathrm{~min}$ ). The $k$ and $t_{1 / 2}$ values of the $\mathrm{Fe}_{90} \mathrm{~B}_{10}$ and $\mathrm{Fe}_{70} \mathrm{~B}_{30} \mathrm{C}$-ZVI powders are $0.068 \mathrm{~min}^{-1}$ and $10.2 \mathrm{~min}$ and $0.134 \mathrm{~min}^{-1}$ and $5.2 \mathrm{~min}$, respectively. These results show the same trends as the decolorization ratios. Here, the half-life period, $t_{1 / 2}$, was used as a comparison parameter for the degradation efficiency to directly compare with data from other studies [16, 19]. The
Table 1 Results of the nonlinear regression of the degradation curves and the halflife periods $\left(t_{1 / 2}\right)$

\begin{tabular}{llllrl}
\hline Sample composition & $C_{0}(\mathrm{mg} / \mathrm{L})$ & $C_{\text {ultimate }}(\mathrm{mg} / \mathrm{L})$ & $k\left(\mathrm{~min}^{-1}\right)$ & $t_{1 / 2}(\mathrm{~min})$ & $r^{2}$ \\
\hline $\mathrm{Fe}_{90} \mathrm{~B}_{10} \mathrm{C}-\mathrm{ZVI}$ & 20.0 & 2.0128 & 0.068 & 10.2 & 0.9761 \\
$\mathrm{Fe}_{70} \mathrm{~B}_{30} \mathrm{C}-\mathrm{ZVI}$ & 20.0 & 0.2855 & 0.134 & 5.2 & 0.9966 \\
$\mathrm{Fe}_{43.64} \mathrm{~B}_{56.36} \mathrm{C}-\mathrm{ZVI}$ & 20.0 & 0.2006 & 0.213 & 3.3 & 0.9967 \\
$\mathrm{Fe}_{70} \mathrm{Si}_{30} \mathrm{C}-\mathrm{ZVI}$ & 20.0 & 2.0653 & 0.046 & 15.1 & 0.9884 \\
$\mathrm{Fe}_{70} \mathrm{Si}_{10} \mathrm{~B}_{20} \mathrm{G}-\mathrm{ZVI}$ & 20.0 & 1.0978 & 0.100 & 6.9 & 0.9864 \\
$\mathrm{Fe}_{70} \mathrm{Si}_{10} \mathrm{~B}_{20} \mathrm{C}-\mathrm{ZVI}$ & 20.0 & 0.3172 & 0.099 & 7.0 & 0.9976
\end{tabular}


amorphous and crystalline $\mathrm{Fe}_{70} \mathrm{Si}_{10} \mathrm{~B}_{20}$ powders both had high degradation efficiencies, which were similar to those of other amorphous Fe-based metallic glass reactants $[14,16,19]$. Then, a question arises: Is the glassy structure of ZVI prerequisite for high efficiency degradation to azo dyes?

To further confirm the above results, another two metallic glass ZVI powders, which were proposed by other researchers as effective reactants for the degradation of azo dyes, were selected for the comparison of the experiments $[14,16] . \mathrm{Fe}_{73} \mathrm{~B}_{17} \mathrm{Nb}_{3} \mathrm{Si}_{7}$ and $\left(\mathrm{Fe}_{0.99} \mathrm{Mo}_{0.01}\right)_{78} \mathrm{Si}_{9} \mathrm{~B}_{13} \mathrm{G}-\mathrm{ZVI}$ powders have a high efficiency for degrading "-N=N-" azo bonding with $t_{1 / 2}$ values of 10 and $5 \mathrm{~min}$, respectively $[14,16]$. For these two alloys, G-ZVI powders with a full amorphous structure (see Fig. 1a) and C-ZVI powders with a crystalline structure were obtained using the same preparation procedures as other G-ZVI and C-ZVI powders in this paper. The four ZVI powders were used under the same degradation conditions, and the results are shown in Fig. 3d. The fitted results show that the $t_{1 / 2}$ values of the $\mathrm{Fe}_{73} \mathrm{~B}_{17} \mathrm{Nb}_{3} \mathrm{Si}_{7} \quad$ G-ZVI, $\mathrm{Fe}_{73} \mathrm{~B}_{17} \mathrm{Nb}_{3} \mathrm{Si}_{7}$ C-ZVI, $\left(\mathrm{Fe}_{0.99-}\right.$ $\left.\mathrm{Mo}_{0.01}\right)_{78} \mathrm{Si}_{9} \mathrm{~B}_{13}$ G-ZVI and $\left(\mathrm{Fe}_{0.99} \mathrm{Mo}_{0.01}\right)_{78} \mathrm{Si}_{9} \mathrm{~B}_{13} \mathrm{C}-\mathrm{ZVI}$ powders are 10.6, 9.5, 11.4 and $10 \mathrm{~min}$, respectively. For these two alloys, the ball-milled powders (C-ZVI) have relatively higher degradation efficiencies than those of their amorphous counterparts (G-ZVI), which further indicates that ball-milled ZVI powders can ensure optimal structures and degradation efficiencies as high as those of their amorphous counterparts.

To obtain elemental information on the outermost atomic layers before and after the degradation, XPS was used to identify the surface chemical states of Fe-B C-ZVI. (See Fig. 4.) Using a nonlinear least squares curve fitting with a mixed Gaussian-Lorentzian function in the XPSPeak 4.1 program, the results of the XPS analysis show that the surfaces of Fe-B C-ZVI powders are covered with complex reaction layers. According to the references [23-25], the possible compositions are the following: For $\mathrm{Fe}-\mathrm{B} \mathrm{C}-\mathrm{ZVI}$, the surface layer contains a mixture of $\mathrm{Fe}^{0}$ (706.7, 719.9 eV), $\mathrm{Fe}_{2} \mathrm{O}_{3}(710.7,724.3 \mathrm{eV}), \mathrm{B}^{0}(187.7 \mathrm{eV})$ and $\mathrm{B}_{\mathrm{x}} \mathrm{O}_{\mathrm{y}}(192.2 \mathrm{eV})$ prior to the degradation. Electronenriched metal active sites repel the adsorption of oxygen atoms, but they are strongly adsorbed by electron-deficient boron. In other words, boron is easily oxidized to generate $\mathrm{B}_{x} \mathrm{O}_{y}$, which effectively protects the metals from oxidation [24]. After degradation, the surface chemical state changes. The surface layer contains $\mathrm{Fe}^{0}(706.7 \mathrm{eV}), \mathrm{Fe}_{2} \mathrm{O}_{3}(710.7$, $724.3 \mathrm{eV}), \mathrm{Fe}^{3+}[711.5 \mathrm{eV}$, possibly $\gamma$-FeOOH; $713.4 \mathrm{eV}$, possibly $\left.\mathrm{Fe}_{2}\left(\mathrm{SO}_{4}\right)_{3}\right], \mathrm{B}^{0}(187.7 \mathrm{eV})$ and $\mathrm{B}_{x} \mathrm{O}_{y}(192.2 \mathrm{eV})$. During the degradation process, the peak area of $\mathrm{Fe}^{0}$ decreases and $\mathrm{Fe}^{3+}$ peaks appear, indicating that $\mathrm{Fe}^{0}$ is consumed or oxidized during the degradation process. The peak area of $\mathrm{B}_{x} \mathrm{O}_{y}$ decreases because it dissolves in the aqueous solution, and the exfoliation rate of the borate stripping from the surface is much larger than that of the iron oxides [18]. The reactive activity is closely related to the surface active sites. Although G-ZVI has long-range disorder, the short-range order in the nanometer scale can be identified. Nanoscale Fe-poor clusters or Fe-rich clusters are common in amorphous iron alloys [26, 27]. The nanometer Fe-rich clusters and Fe-poor clusters constitute galvanic cells, which help iron lose electrons and degrade azo dyes [19]. In the C-ZVI alloys, the hard boron particles are embedded in the soft $\alpha$-iron particles (see Fig. 1c) during ball-milling. The embedded boron particles in the iron matrix also constitute galvanic cells, which have a different scale than those in G-ZVI. These galvanic cells on the micrometer scale also contribute to iron losing electrons and promote the degradation process of MO. These active sites increase with the boron content, and therefore, C-ZVI, which has a higher boron content, has a higher degradation efficiency. Numerous studies have shown that the dissociative adsorption of $\mathrm{H}_{2} \mathrm{O}$ occurs on $\mathrm{Fe}^{0}$ surfaces to produce atomic hydrogen [28-30]. The atomic hydrogen can combine to form $\mathrm{H}_{2}$ or react with other compounds in the system. Because the potential of boron is lower than that of iron $\left(\mathrm{E}_{0}\right.$ for $\mathrm{B}$ is $-0.869 \mathrm{eV} ; \mathrm{E}_{0}$ for $\mathrm{Si}$ is $-0.78 \mathrm{eV}$ ), boron can play a more vital role in corrosion behavior than silicon [31]. Therefore, the degradation efficiency of $\mathrm{Fe}_{70} \mathrm{~B}_{30}$ powders is significantly higher than that of $\mathrm{Fe}_{70} \mathrm{Si}_{30}$ powders. Once the corrosion begins, the corrosion rate of C-ZVI is faster than that of G-ZVI due to crystal defects, which assists $\mathrm{Fe}^{0}$ in losing electrons. Meanwhile, boron and iron were assembled into galvanic cells in the MO solution, which dissociate $\mathrm{H}_{2} \mathrm{O}$ to produce adsorbed atomic hydrogen. The atomic hydrogen reacts with the azo bonds of MO molecules to form $N, N$ dimethylbenzenamine $\quad\left(\mathrm{C}_{8} \mathrm{H}_{11} \mathrm{~N}\right), \quad N, N$-dimethyl- $p$ phenylenediamine $\left(\mathrm{C}_{8} \mathrm{H}_{12} \mathrm{~N}_{2}\right)$ and sulfanilic acid $\left(\mathrm{C}_{6} \mathrm{H}_{6}\right.$ $\mathrm{NSO}_{3}$ ). Therefore, a higher boron content results in more galvanic cells and higher degradation efficiency [19].

\section{Conclusions}

To summarize, the degradation efficiencies of ZVI with amorphous structures and crystalline powders prepared by ball-milling were comprehensively evaluated. The results showed that ZVI powders have a high degradation efficiency to MO similar to that of their amorphous counterparts with the same composition. $\mathrm{Fe}_{70} \mathrm{Si}_{10} \mathrm{~B}_{20} \mathrm{G}-\mathrm{ZVI}$ and $\mathrm{Fe}_{70} \mathrm{Si}_{10} \mathrm{~B}_{20} \mathrm{C}$-ZVI have similar particle size distributions, surface morphologies and $t_{1 / 2}$ values $(6.9$ and $7 \mathrm{~min}$, respectively), as do $\mathrm{Fe}_{73} \mathrm{~B}_{17} \mathrm{Nb}_{3} \mathrm{Si}_{7}$ and $\left(\mathrm{Fe}_{0.99} \mathrm{Mo}_{0.01}\right)_{78-}$ $\mathrm{Si}_{9} \mathrm{~B}_{13} \mathrm{G}-\mathrm{ZVI}$ and C-ZVI powders. The non-metallic elements play an important role in the degradation process. 

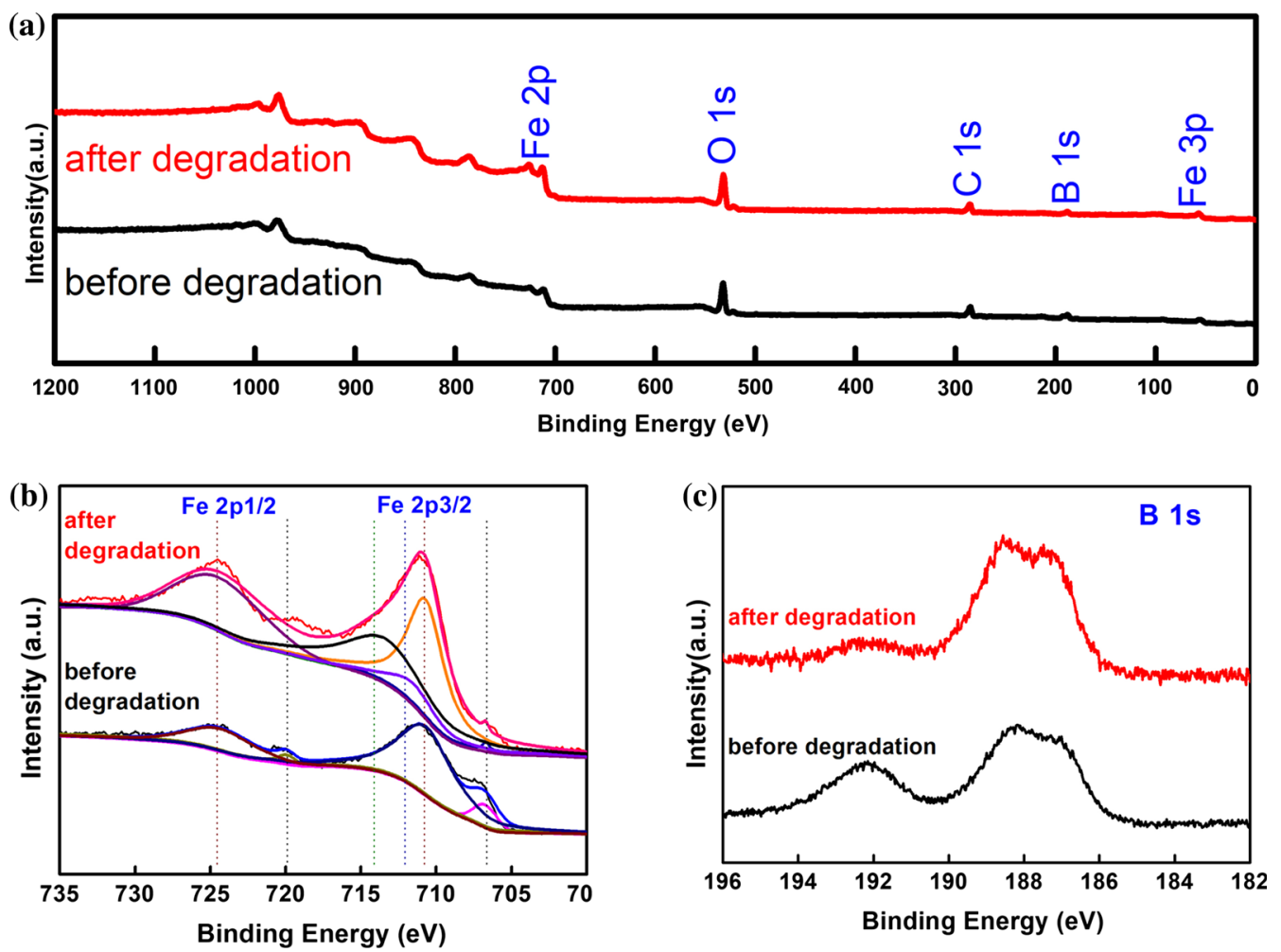

Fig. 4 X-ray photoelectron spectra of the Fe-B C-ZVI surfaces before and after degradation: a X-ray photoelectron spectra survey scan, $\mathbf{b}$ Fe $2 p$ and $\mathbf{c}$ B $1 s$ photoelectron spectra

Boron particles embed into iron particles to form numerous galvanic cells, which favor the loss of electrons from iron and promote the degradation process. These favorable structures function in the same way as the amorphous ZVI and contribute to a high degradation efficiency. Because increasing the boron content can result in more active sites and more galvanic cells, the degradation efficiency of ZVI to MO increases with the boron content. The $t_{1 / 2}$ of $\mathrm{Fe}_{43.64} \mathrm{~B}_{56.36}$ powder is $3.3 \mathrm{~min}$, which is half that of the $\mathrm{Fe}_{70} \mathrm{Si}_{10} \mathrm{~B}_{20}$ G-ZVI and C-ZVI powders. It is widely accepted that amorphous ZVI has a high degradation activity for azo dyes. However, a simple and cheap processing method (ball-milling) can prepare crystalline ZVI powders with favorable structures and $\mathrm{MO}$ degradation efficiencies comparable to or higher than amorphous ZVI powders. These findings may provide a highly efficient, low-cost, commercial method for azo dye wastewater treatment.

Acknowledgements This work was financially supported by the Program of Introducing Innovative Research Team in Dongguan under Contract Number 2014607109 and Shenzhen Science and Technology Research Grants under Contract Numbers JCYJ20160422104921235, JCYJ20160422143659258 and JCYJ2016 0422144751573.

\section{References}

[1] T. Robinson, G. McMullan, R. Marchant, P. Nigam, Bioresour. Technol. 77, 247 (2001)

[2] İ. Arslan, I.A. Balcioğlu, T. Tuhkanen, Chemosphere 39, 2767 (1999)

[3] R.G. Saratale, G.D. Saratale, J.S. Chang, S.P. Govindwar, J. Taiwan Inst. Chem. Eng. 42, 138 (2011)

[4] K.T. Chung, J. Environ. Sci. Health C 34, 233 (2016)

[5] S.D. Kalme, G.K. Parshetti, S.U. Jadhav, S.P. Govindwar, Bioresour. Technol. 98, 1405 (2007)

[6] R. Sivaraj, C. Namasivayam, K. Kadirvelu, Waste Manag 21, 105 (2001)

[7] M. Punzi, A. Anbalagan, R. Aragão Börner, B.M. Svensson, M. Jonstrup, B. Mattiasson, Chem. Eng. J. 270, 290 (2015)

[8] P.V. Nidheesh, R. Gandhimathi, S.T. Ramesh, Environ. Sci. Pollut. Res. 20, 2099 (2013)

[9] W. Feng, D. Nansheng, H. Helin, Chemosphere 41, 1233 (2000)

[10] Y. Liu, X. Chen, J. Li, C. Burda, Chemosphere 61, 11 (2005)

[11] Z. Xiao, Q. Zhou, H. Qin, J. Qiao, X. Guan, Desalin. Water Treat. 57, 1659 (2016)

[12] H. Liu, G. Li, J. Qu, H. Liu, J. Hazard. Mater. 144, 180 (2007)

[13] J. Fan, Y. Guo, J. Wang, M. Fan, J. Hazard. Mater. 166, 904 (2009)

[14] C. Zhang, H. Zhang, M. Lv, Z. Hu, J. Non. Cryst. Solids 356, $1703(2010)$

[15] B. Lin, X. Bian, P. Wang, G. Luo, Mater. Sci. Eng. B 177, 92 (2012)

[16] J.-Q. Wang, Y.-H. Liu, M.-W. Chen, G.-Q. Xie, D.V. Louzguine-Luzgin, A. Inoue, J.H. Perepezko, Adv. Funct. Mater. 22, 2567 (2012) 
[17] S. Das, V. Bandi, H.S. Arora, M. Veligatla, S. Garrison, F. D’Souza, S. Mukherjee, J. Mater. Res. 30, 1121 (2015)

[18] Y. Tang, Y. Shao, N. Chen, X. Liu, S.Q. Chen, K.F. Yao, RSC Adv. 5, 34032 (2015)

[19] S. Xie, P. Huang, J.J. Kruzic, X. Zeng, H. Qian, Sci. Rep. 6, 21947 (2016)

[20] R. Khan, S.W. Kim, T.J. Kim, C.M. Nam, Mater. Chem. Phys. 112, 167 (2008)

[21] J. Thibaud, Nature 121, 321 (1928)

[22] H.Y. Shu, M.C. Chang, H.H. Yu, W.H. Chen, J. Colloid Interface Sci. 314, 89 (2007)

[23] D.G. Tong, W. Chu, P. Wu, G.F. Gu, L. Zhang, J. Mater. Chem. A 1, $358(2013)$

[24] R. Fernandes, N. Patel, A. Miotello, M. Filippi, J. Mol. Catal. A Chem. 298, 1 (2009)
[25] R. Jain, N.S. Saxena, K.V.R. Rao, D.K. Avasthi, K. Asokan, Mater. Sci. Eng. A 297, 105 (2001)

[26] Q. Hu, X.R. Zeng, M.W. Fu, Appl. Phys. Lett. 97, 96 (2010)

[27] K. Brzbzka, A. Slawska-waniewska, P. Nowicki, K. Jezuita, Mater. Sci. Eng. A 228, 654 (1997)

[28] L.J. Matheson, P.G. Tratnyek, Environ. Sci. Technol. 28, 2045 (1994)

[29] P.A. Thiel, T.E. Madey, Surf. Sci. Rep. 7, 211 (1987)

[30] W.H. Hung, J. Schwartz, S.L. Bernasek, Surf. Sci. Lett. 248, 332 (1991)

[31] S.M. Ponder, J.G. Darab, J. Bucher, D. Caulder, I. Craig, L. Davis, N. Edelstein, W. Lukens, H. Nitsche, L. Rao, Chem. Mater. 13, 479 (2001) 